\title{
Decision Support System For Selecting Bali Tourist Attractions Using The PROMETHEE Method
}

\author{
Eva Zuraidah \\ STMIK Nusa Mandiri / Sistem Informasi \\ Jl. Kramat Raya No . 18 Jakarta Pusat \\ eva.evz@nusamandiri.ac.id
}

\begin{abstract}
Tourism is currently very potential to be developed as a source of local income by providing information both online and offline to the community so that regional income increases. Bali is one of the tourist destinations in Indonesia which is visited by many local and foreign tourists. The island of Bali has many interesting sights consisting of natural attractions, royal festivals, culinary tours, traditional markets, and museums. There are many criteria that must be considered, so through this recommendation system, tourists can find out what places are in Bali they will visit. One of the problems of decision making with many criteria and attributes in the selection of attractions is to provide detailed decisions that refer to the scale of weight possessed. Decision support systems provide priority results of attractions that are suitable for every traveler. Traveling is very important because with tourism we can eliminate fatigue due to activity during the day. The selection of the right tourist attraction also affects this, so it is necessary to choose the right tourist attraction. This study focused on the application of multi-attribute decision making (MADM) to decision support systems (SPK) using preferred organizational methods for enrichment and evaluation (Promeethe). When a traveler fills out a questionnaire, he must be consistent with the answers to get the best results based on his willingness and characteristics. This research uses descriptive analysis method that presents a summary of the results of surveys and interviews of tourists who want to choose Bali tourist attractions according to costs, security, natural beauty, facilities, and infrastructure and location.
\end{abstract}

Keywords: Decision Support System , Bali Tour, PROMETHEE

\section{INTRODUCTION}

Beach, its culture, its custom which is passed down by the ancestors of the Indonesian nation and thus gives an impression that will not be forgotten and is a leading and unique tour in Indonesia.

The island of Bali, which is part of a small Sunda archipelago, has a total area of 153 kilometers with a width of 112 kilometers and is located on the 8th southern latitudes, as well as tropical climates. The capital of Bali is the city of Denpasar, on the island of Bali there is also the city of Ubud which is the center of art, there is also Kuta Sanur, Nusa Dua.
Decision-making is an appropriate form for the selection of some or alternatives chosen in the process through a particular mechanism in the hope of a good decision-making, always objective, quick and precise. The island of Bali many beautiful attractions, foreign tourists and tourists in the city more choices such as natural beauty, security, the distance that is nearby, facilities and infrastructure.

Many tourists find it difficult to know which sights are beautiful, comfortable, safe, and do not waste time to visit the sights, can use the decisionmaking system and use the preference function method for the preference ranking organizational method for enrichment evaluation (PROMETHEE). 
The tourism industry has grown and developed rapidly today and is one of the sources of foreign exchange income in the country of Indonesia. To make it easier for tourists in the country and abroad to find more tourist attractions with accurate information and recommendation of tourism object selection in accordance with the criteria chosen, it needs a computerized system that contains all tourist area information online. [1]

Decision support system is an interactive information system that provides information, modeling, and data manipulation. The system is used to assist decisions in semi-structured situations and unstructured situations, where no one knows exactly how decisions should be made [2]

The program is a collection of instructions that are used to set up a computer to perform a certain action .. Computers include three important aspects of hardware, software, intellectual devices or people who play a role in computer operations and software development. [3]

Fuzzy Preference Ranking Organization Methode for Enrichment Evaluation method to evaluate four potential suppliers based on seven criteria and four decision makers using realistic case studies. Ranking results provide references to help decision makers or organizations to improve the efficiency of their IT outsourcing decision process emerging with the best solution. [4]

The function of new logistics preferences, which can be used for continuous performance data. The proposed logistics preferential function is used in telecommunication operator performance data from the Ghana National Communications Authority. When used in the PROMETHEE methodology, the proposed logistic preferences function and Gaussian preferences function produce the same rank sequence. However, the proposed logistic preferences function is performed more efficiently than the Gaussian preferences function [5]

Decision support systems are interactive information systems that provide information, modeling, and manipulation of data. The system is used to assist decisions in structured situations and unstructured situations, where no one knows exactly how decisions should be made. Decision support systems are usually built to support solutions to a problem or to evaluate an opportunity. Such a decision support system is called a decision support system application.[6]

Decision system is a branch of knowledge that is located between information systems and intelligent systems. The decision-making process of various alternatives is needed so that a criterion is needed.[7]
The choice of Aceh tourism using a decision support system still has weaknesses in terms of displaying rankings and without any other recommendations for prospective tourists, so it is still less effective in determining the tourist objects that want to be visited.[8]

\section{RESEARCH METHOD}

\section{Multi-Criteria Decision Making (MCDM)}

Decisions are a set of actions that need to be followed in solving problems to avoid or undermine negative impacts or to take advantage of opportunities. Decision making by organizations or individuals has helped a lot in maintaining the existence of an organization or individuals who have helped in problem-solving activities.

In the recommender system, items of interest and user preferences are represented in various forms. This system uses one or more attributes to describe an item. Especially in systems where recommendations are based on the opinions of others, it is important to consider some of the criteria affecting users so as to make more effective recommendations.

The criteria used in promethee can be seen in table 1 which contains basic data analysis with multicriteria

Citeria dominance.

The $f$ value is the real value of a criterion, $\mathrm{f}: \mathrm{K} \rightarrow$ Я (Real Word).

Submission of Intensity (P) from alternative preference a to alternative $\mathrm{b}$ that is:

1) $P(a, b)=0$, means there is no difference between $a$ and $b$, or no preference of $a$ is better than $b$.

2) $\mathrm{P}(\mathrm{a}, \mathrm{b}) \approx 0$, meaning weak preference of $\mathrm{a}$ is better than $b$.

3) $\mathrm{P}(\mathrm{a}, \mathrm{b})=1$, the strong preference of $\mathrm{a}$ is better than $b$.

4) $\mathrm{P}(\mathrm{a}, \mathrm{b}) \approx 1$, means the absolute preference of $a$ is better than $b$

In this method the preference function often results in different function values between the two evaluations, so that: $P(a, b)=P(f(a)-f(b))$.

formula weighting criteria calculation

$$
\mathrm{W}_{\mathrm{j}}=\frac{\mathrm{w}_{\mathrm{j}}}{\sum \mathrm{w}_{\mathrm{i}}} \text { atau } \sum \mathrm{w}_{\mathbf{j}} \mathbf{1}
$$

Then we get the comparison formula for each alternative, as follows:

$$
\square\left(\mathrm{a}_{1} ; \mathrm{a}_{\mathrm{i}}\right)=\sum_{\mathrm{j}=1} \mathrm{~W}_{\mathrm{j}} \times \mathrm{P}_{\mathrm{j}}\left(\mathrm{a}_{1} ; \mathrm{a}_{\mathrm{i}}\right)
$$


Ranking in the PROMETHEE method consists of:

1) Entering flow, the approaching direction of node a and this is the character of outrangking measurement. For each node a in the graph the outrangking value is determined based on the entering flow with the equation

$$
\varnothing-\left(\mathrm{a}_{1}\right)=\sum_{\mathrm{i}=1} \square\left(\mathrm{a}_{1} ; \mathrm{a}_{\mathrm{i}}\right)
$$

2) Leaving flow, the sum of which has direction away from node a. and this is an outranking measure. with the equation

$$
\varnothing\left(a_{1}\right)=\varnothing+\left(a_{1}\right)-\varnothing-\left(a_{1}\right)
$$

3) Net Flow, So the consideration in determining the Net flow obtained by the equation

$$
\varnothing+(\mathrm{a} 1)=\sum_{\mathrm{i}=1}^{\mathrm{I}} \square\left(\mathrm{a}_{1} ; \mathrm{a}_{\mathrm{i}}\right)
$$

Information

a) $f(a, x)=$ indicates a preference that the alternative is better than alternative $x$.

b) $\mathrm{f}(\mathrm{x}, \mathrm{a})=$ indicates a preference that alternative $\mathrm{x}$ is better than an alternative

c) $\mathrm{F}+(\mathrm{a})=$ Leaving flow, used to determine the priority order onPromethee I process using partial order.

d) F- (a) = Entering flow, used to determine the priority order in the Promethee I process using partial order.

e) $\mathrm{F}(\mathrm{a})=$ Net flow, used to generate the final decision of the ordering of the sequence in solving the problem so as to produce a complete sequence

f) $($ a1 $)=1$ st alternative

g) (ai) $=$ an infinite alternative

h) $\mathrm{Wj}=$ criteria weight

i) $\varnothing+($ a1 $)=$ Leaving flow, used to determine the order of priority in the promethee process which uses partial sequences.

j) $\varnothing-(\mathrm{a} 1)=$ Entering flow, used to determine the order of priority in the promethee process that uses partial sequences.

k) $\varnothing(\mathrm{a})=$ Net flow, used to produce the final decision on the determination of the problem in solving the problem so as to produce a complete sequence.

1) $\mathrm{Wi}=$ Number of Criteria

\section{RESULTS AND ANALYSIS}

Data collection technique

In this research data collection technique using questionnaire method

\section{RESULTS}

1. The research begins with observations using the descriptive-analytic method by presenting the summary of survey results.

2. Process needs, required to process input data into output data in the form of desired information that is, Process calculate for the parameter value, Process calculate Leaving flow value, Process calculates the value of Entering flow and Process calculate net flow value.

3. The design of the model uses the preferred method of organization for enrichment evaluation with the determination of the alternatives chosen and the most desirable among the location, facilities, time, cost, distance, security. Alternative symbols or alternatives used: beach, the lot, creations park, waterfall by determining the ranking in method preference method of organization for enrichment evaluation that gives value/weight for each criterion.

4. There are 4 types of weighting values defined, ie 1 (low priority) to 4 (highly prioritized).

5. Determination of parameters, The parameters that apply to each preference will be different, following the selected preferences are $\mathrm{q}$ and $\mathrm{p}$. The parameter values of each preference are determined by the decision maker with regard to the appropriate constraints for each criterion.

6. The design of the model uses the preferred method of organization for enrichment evaluation with the determination of the chosen alternative and the most desirable of them are the beach, land lot, gitgit waterfall, the garden of creation.

7. After the results of the questionnaire obtained then the data is entered into several criteria that have been determined, as for the following criteria: f1 (.): Price, f2 (.): Security, f3 (.): Beauty f4 (.): Facilities and infrastructure, f5 (.): distance f6 (.): strategic location.

8. The results of the preference analysis will be used to calculate the value of Leaving Flow, Entering Flow and Net Flow of each alternative. The greatest value of Net Flow indicates that the alternative is a highly prioritized alternative to choose Bali island tourism, and for which the smallest Net Flow value indicates that the alternative is an alternative with low priority or not recommended. In Table 2 the criteria value of each alternative data of the questionnaire results. 
Table 2 Alternative questionnaire results

\begin{tabular}{|c|c|c|c|c|c|c|c|c|c|}
\hline \multirow[b]{2}{*}{$\begin{array}{l}\text { CRITE } \\
\text { RIA }\end{array}$} & \multirow[b]{2}{*}{$\begin{array}{l}\text { Min } \\
\text { Maks }\end{array}$} & \multirow[b]{2}{*}{$\begin{array}{l}\text { Bobo } \\
t\end{array}$} & \multicolumn{4}{|c|}{ Alternatif } & \multirow{2}{*}{$\begin{array}{c}\mathrm{Ti} \\
\text { pe } \\
\text { Pre } \\
\text { fer } \\
\text { ens } \\
\text { i }\end{array}$} & \multicolumn{2}{|c|}{ Parameter } \\
\hline & & & $\begin{array}{l}\text { Bea } \\
\text { ch }\end{array}$ & $\begin{array}{l}\text { La } \\
\text { nd } \\
\text { Lot }\end{array}$ & $\begin{array}{l}\text { Recre } \\
\text { ationa } \\
1 \text { Park }\end{array}$ & $\begin{array}{l}\text { Gitgit } \\
\text { Water } \\
\text { fall }\end{array}$ & & $\mathrm{q}$ & $\mathrm{p}$ \\
\hline Price & $\begin{array}{c}\text { minim } \\
\text { al }\end{array}$ & 0,1 & 20 & 20 & 10 & 10 & 3 & & 4 \\
\hline Security & $\begin{array}{c}\operatorname{maxi} \\
\text { mal }\end{array}$ & 0,25 & 60 & 80 & 80 & 80 & 3 & & 40 \\
\hline Beauty & $\begin{array}{c}\operatorname{maxi} \\
\text { mal }\end{array}$ & 0,25 & $\begin{array}{r}400 \\
0 \\
\end{array}$ & $\begin{array}{r}500 \\
0 \\
\end{array}$ & 2500 & 2500 & 4 & $\begin{array}{l}60 \\
0 \\
\end{array}$ & 600 \\
\hline $\begin{array}{l}\text { Infratru } \\
\text { kture }\end{array}$ & $\begin{array}{c}\operatorname{maxi} \\
\text { mal }\end{array}$ & 0,2 & 90 & 80 & 90 & 70 & 2 & 40 & \\
\hline Distance & $\begin{array}{c}\text { minim } \\
\text { al }\end{array}$ & 0,1 & 2 & 4 & 2 & 4 & 5 & 2 & 3 \\
\hline $\begin{array}{l}\text { Strategi } \\
\mathrm{c} \\
\text { location }\end{array}$ & $\begin{array}{c}\operatorname{maxi} \\
\text { mal }\end{array}$ & 0,1 & 46 & 50 & 50 & 60 & 1 & & \\
\hline
\end{tabular}

9. Determination of preference index After the data obtained then made a matrix of preference index data that has gone through the stages of calculation in determining the value of preference index presented in Table 3

Table 3 Determination of preference index

\begin{tabular}{|l|r|r|r|r|r|r|}
\hline Alternatif & Beach & Land Lot & $\begin{array}{l}\text { Recreatio } \\
\text { nal Park }\end{array}$ & \multicolumn{1}{c|}{$\begin{array}{c}\text { Gitgit } \\
\text { Waterfall }\end{array}$} & Total & Leaving \\
\hline Beach & 0 & 0,15 & 0,125 & 0,55 & 0,825 & 0,275 \\
\hline Land Lot & 0,35 & 0 & 0,25 & 0,5 & 1,1 & 0,36667 \\
\hline $\begin{array}{l}\text { Recreation } \\
\text { al Park }\end{array}$ & 0,225 & 0,3 & 0 & 0,55 & 1,075 & 0,35833 \\
\hline $\begin{array}{l}\text { Gitgit } \\
\text { Waterfall }\end{array}$ & 0,1 & 0,1 & 0,1 & 0 & 0,3 & 0,1 \\
\hline Total & 0,675 & 0,55 & 0,475 & 1,6 & & \\
\hline Entering & 0,225 & 0,1833333 & 0,158333 & 0,5333 & & \\
\hline
\end{tabular}

10. Determination of Leaving Flow, Entering Flow and Net Flow After the preference index calculation is done based on the above matrix data then calculate the Leaving flow, Entering flow and net flow value. The values can be seen in Table 4

Table 4 Leaving flow value, Entering flow and Net flow

\begin{tabular}{|c|r|r|r|r|}
\hline Alternatif & \multicolumn{1}{|c|}{$\begin{array}{c}\text { Leaving } \\
\text { Flow }\end{array}$} & \multicolumn{1}{|c|}{$\begin{array}{c}\text { Entering } \\
\text { Flow }\end{array}$} & Net Flow & Urutan \\
\hline Beach & 0,275 & 0,225 & 0,05 & 3 \\
\hline Land Lot & 0,3667 & 0,1833 & 0,18333 & 2 \\
\hline $\begin{array}{c}\text { Recreational } \\
\text { Park }\end{array}$ & 0,3583 & 0,1583 & 0,2 & 1 \\
\hline $\begin{array}{c}\text { Gitgit } \\
\text { Waterfall }\end{array}$ & 0,1 & 0,5333 & $-0,43333$ & 4 \\
\hline
\end{tabular}

\section{Conclusion}

This research can help the prospective visitor of the domestic and foreign tourists to choose the right tourist attraction although it has many criteria and alternatives such as beaches, garden creations, lot lands, many git waterfalls, the creation of the island of Bali. It can be seen on alternatives ranging from price, security, beauty, infrastructure and strategic location.

Decision support systems for selecting object locations using the Preferences Method Method The Organizational Method for Enrichment Evaluation can be further developed by adding other criteria that can support appropriate decision-making.

The system can be further expanded by adding more features for users to choose what method to use and can compare results with more varied and accurate methods

\section{REFERENCES}

[1] Oktovianus, "Support System of Tourism Places Selection in East Timor By Lectre Method," 2014.

[2] E.B.S.Syahrani Dhimas Prabowo, "Decision Supporting Museum of Decision to Revitalize Building and Cultural Heritage Area of Bandung City in Disbudpar, Bandung City. V, "2015.

[3] Hariman and Komar Rusmana. (2014). "Decision Support Approval In The Determination of Natural Attraction Using AHP Method Based Android". Bandung: STMIK LPKIA

[4] Tien-Chin Wang, Lisa Y. Chen, Ying-Hsiu Chen; 2018 "Applying Fuzzy PROMETHEE Method for Evaluating IS Outsourcing Suppliers", 9780-7695-3305-6 / 08 2008 IEEE DOI 10.1109/ FSKD.2008.506

[5] S.K. Amponsah, K. F. Darkwah * and A. Inusah, Logistic preference function for preference Ranking organization method for enrichment evaluation(PROMETHEE) decision analysis, African Journal of Mathematics and Computer Science Research Vol. 5 (6), pp. 112-119, 15 March, 2012, ISSN 2006-9731

[6] Syahrani Dhimas Prabowo, Eko Budi Setiawan, 2015. Sistem Pendukung Keputusan Revitalisasi Terhadap Bangunan dan kawasan cagar budaya kota bandung di disbudpar kota bandung. Vol. 2, No. 2, Oktober 2013, ISSN : 2089-9033

[7] A Yani Ranius, 2015. Sistem Pendukung Keputusan Penentuan Destinasi wisata Unggulan dikota Palembang. Prosiding SNIT 
2015 : Hal.A-55

[8] Hariman, Irman dan Rusmana, Komar. (2014). “Aplikasi Pendukung Keputusan Dalam Penentuan Objek Wisata Alam Menggunakan Metode AHP Berbasis Android". JURNAL LPKIA, Vol.1 No.1, September 2014, pp. 1-6. http://jurnal.lpkia.ac.id/ 